\title{
Effects of treatment of preweaning dairy calves with recombinant bovine somatotropin on immune responses and somatotropic axis
}

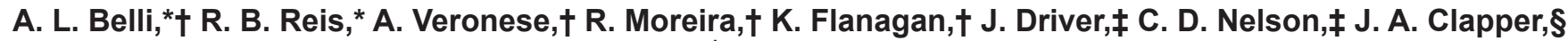 \\ M. A. Ballou,\# K. C. Jeong, $\ddagger$ and R. C. Chebel $\ddagger^{1}$ \\ *Department of Animal Science, Escola de Veterinária da Universidade Federal de Minas Gerais, Belo Horizonte 567 \\ †Department of Large Animal Clinical Sciences, and \\ ‡Department of Animal Sciences, University of Florida, Gainesville 32608 \\ §Department of Animal Science, South Dakota State University, Brookings 57007 \\ \#Department of Animal and Food Sciences, Texas Tech University, Lubbock 79409
}

\begin{abstract}
Weaning may be associated with negative energy balance and body weight loss when calves are still immunologically immature, predisposing them to infectious diseases. The aim of the present experiment was to investigate the effects of treatment of preweaning dairy calves with recombinant bovine somatotropin (rbST) on the somatotropic axis, selected immune parameters, and hematology of calves around weaning. Thirty-six Holstein female calves were randomly assigned to receive 1.5 to $1.8 \mathrm{mg}$ of rbST (Posilac, Elanco Animal Health, Greenfield, IN) per kilogram of body weight or to receive injections of saline (saline solution $0.9 \%$, Valley Vet Supply, Marysville, KS) every $7 \mathrm{~d}$ from 21 to 63 $\mathrm{d}$ of life. Calves were fed milk replacer ad libitum from birth to $38 \mathrm{~d}$ of age $(\mathrm{d}-11)$, when progressive weaning started, and calves were weaned at $49 \mathrm{~d}$ of age (d 0 ). Calves were weighed at birth and weekly from 21 to 63 $\mathrm{d}$ of age, when wither height also was measured. Calves were vaccinated with $0.5 \mathrm{mg}$ of ovalbumin on study d -28 and -7 . Blood samples were collected on $d-28$, $-25,-21,-11,0,3,7$, and 14. Polymorphonuclear leukocytes were isolated and challenged ex vivo with Escherichia coli to determine phagocytosis and oxidative burst capacity. Additionally, expression of cluster of differentiation (CD)62L and CD18 by granulocyte, lymphocyte, and CD14+ monocyte were determined. Blood samples were also used to determine hematological parameters and concentrations of growth hormone, insulin-like growth factor-1, insulin, glucose, fatty acids, $\beta$-hydroxybutyrate, haptoglobin, and anti-ovalbumin IgG. Calves treated with rbST had greater concentrations of growth hormone and insulin-like growth factor- 1 from d -25 to 14 than control calves, whereas in-
\end{abstract}

Received October 9, 2017.

Accepted February 26, 2018.

${ }^{1}$ Corresponding author: rcchebel@ufl.edu sulin, fatty acid, and $\beta$-hydroxybutyrate concentrations did not differ. On d -11 , glucose concentration was greater for rbST-treated calves. Treatment did not affect polymorphonuclear lymphocyte phagocytosis and oxidative burst, but intensity of expression of CD62L and CD18 by granulocytes tended to be increased by rbST treatment. Treatment did not affect the concentration of anti-ovalbumin IgG in serum. Haptoglobin concentration was reduced in rbST treated calves on d 3 and we noted a tendency for hematocrit to be lower in rbST-treated calves. Treatment did not affect body weight, wither height, and average daily gain, despite the fact that rbST-treated calves had lower daily milk replacer intake. The relatively minor improvements in immune responses resulting from rbST treatment of weaning calves may not be sufficient to reduce the incidence of infectious diseases.

Key words: dairy calves, somatotropin, immune parameters

\section{INTRODUCTION}

Neonatal calves are immunologically naive and rely heavily on passive transfer of immunoglobulins through colostrum and on innate immune mechanisms as their first line of defense against pathogens (Barrington and Parish, 2001). The development of the immune system to a mature state is a slow process and percentages of lymphocyte subpopulations [cluster of differentiation (CD) 4+, CD8+, and $\gamma \delta \mathrm{T}$ cell receptor +$]$ and PMN function (phagocytosis and respiratory burst) reach stable levels within the first 6 mo of life (Kampen et al., 2006). On the other hand, the immunoglobulins acquired from colostrum are practically extinguished from circulation by approximately $21 \mathrm{~d}$ of age (Chase et al., 2008; Hulbert and Moisá, 2016), creating a window of susceptibility.

Weaning, which in many herds is also associated with regrouping, is another challenging period for dairy 
calves. Common metabolic changes associated with weaning are decreased circulating concentrations of glucose, insulin, and IGF-1 and increased circulating concentrations of BHB and, in some instances, fatty acids (Omidi-Mirzaei et al., 2015; Schäff et al., 2016). Less is known about the associations between weaning and changes in immune parameters. Hulbert et al. (2011a) demonstrated that calves weaned at $47 \mathrm{~d}$ of age, after being fed $454 \mathrm{~g} / \mathrm{d}$ of milk replacer (DM), had reduced percentage of PMN positive for phagocytosis and oxidative burst and reduced intensity of phagocytosis ex vivo from 45 to $66 \mathrm{~d}$ of age. Researchers have proposed that, to achieve proper weight gain, reproductive performance, and milk yield in the first lactation, calves should be fed 15 to $20 \%$ of their live BW of milk containing 20 to $25 \%$ fat and $28 \%$ protein (DM basis; Gelsinger et al., 2016; Soberon et al., 2012). A significant challenge for this strategy is the weaning period, because calves may not consume enough solid feed (starter and forage) to compensate for the nutritional needs in the absence of milk feeding (Miller-Cushon et al., 2013). Therefore, calves undergoing weaning may present negative energy balance and, consequently, alterations in metabolic profile that could impair immune function.

Insulin-like growth factor-1 is an important factor in proliferation, differentiation, and hypertrophy of various cell types, including immune cells (LeRoith and Roberts, 1991). Culture of human granulocytes in the presence of increasing concentrations of IGF-1 reduced the percentage of apoptotic granulocytes by 34 to $40 \%$ compared with culture of granulocytes in the absence of IGF-1 (Kooijman et al., 2002). Similarly, granulocyte cultured with $6.5 \mathrm{n} M$ IGF-1 had a $45 \%$ decrease in DNA fragmentation compared with granulocytes cultured in the absence of IGF-1 (Kooijman et al., 2002). Culture of PMN with human growth hormone $(\mathbf{G H} ; 100$ to $1,000 \mathrm{ng} / \mathrm{mL}$ ) or IGF-1 (100 to $1,000 \mathrm{ng} / \mathrm{mL}$ ) increased the percentage of Escherichia coli killed and increased the expression of CD11 (Inoue et al., 1998). Treatment of humans and rats deficient in $\mathrm{GH}$ with somatotropin (ST) resulted in increased circulating concentrations of IGF-1, PMN, and total antibodies (Kimata and Yoshida, 1994; Ibañez et al., 2005; Sohmiya et al., 2005). Thus, the reduced concentration of IGF-1 observed during the weaning period could partly explain the immunosuppression observed during this phase of life. Piglets treated with porcine ST $(0.5 \mathrm{mg} / \mathrm{kg})$ for $5 \mathrm{~d}$ and subjected to weaning and transportation had increased circulating concentrations of IGF-1, neutrophils, and IgM in the first $24 \mathrm{~h}$ after weaning compared with piglets not treated with ST and subjected to weaning and transportation stress (Kojima et al., 2008). In recent experiments, our group demonstrated that cows treated with $125 \mathrm{mg}$ of recombinant (r)bST from -21 to $28 \mathrm{~d}$ relative to calving, a period characterized by intense negative energy balance and immunosuppression, had greater intensity of phagocytosis and oxidative burst by PMN, greater circulating concentration of antiovalbumin IgG, and reduced incidence of retained fetal membranes and metritis (Silva et al., 2015, 2017a).

The hypotheses of the current experiment were that treatment of weaning calves with rbST would increase GH and IGF-1 concentrations and, consequently, improve selected innate and adaptive immune parameters. Additionally, we hypothesized that treatment of weaning calves with rbST would only minimally affect metabolic parameters. Therefore, the objectives of the current experiment were to evaluate the effects of treating weaning calves with rbST on GH and IGF-1 concentrations, on PMN phagocytosis and oxidative burst, on expression of adhesion molecules by granulocytes, lymphocytes, and CD14+ monocytes, on concentration of anti-ovalbumin $\mathrm{IgG}$, and on hematological parameters. The secondary objectives of the current experiment were to evaluate the effects of treating weaning calves with rbST on metabolic parameters, growth, and intake of milk replacer.

\section{MATERIALS AND METHODS}

All procedures involving animals were approved by the animal care and use committee of the University of Florida (protocol \#201609265).

\section{Animals, Facilities, Nutrition, and Management}

The experiment was conducted on a commercial dairy farm located in northern Florida. Calves were born in a loose housing sand-bedded pen. At birth, calves were individually weighed using an electronic scale and fed $2 \mathrm{~L}$ of colostrum within $30 \mathrm{~min}$ of birth and another 2 $\mathrm{L}$ of colostrum within $6 \mathrm{~h}$ of birth. At $48 \mathrm{~h}$ after birth, blood was sampled to determine serum total protein, a proxy for passive transfer of immunity. Only calves with total protein measured by refractometer between 5.5 and $8.5 \mathrm{~g} / \mathrm{dL}$ were used in this experiment. Throughout the experiment, calves were group housed $(8$ calves/pen from $24 \mathrm{~h}$ after birth to $20 \mathrm{~d}$ of age, 20 to 30 calves/pen from 21 to $63 \mathrm{~d}$ of age) in sand-bedded pens.

From $24 \mathrm{~h}$ after birth to $36 \mathrm{~d}$ of age, calves were fed milk replacer ad libitum. Starting at $38 \mathrm{~d}$ of age, milk replacer allowance was progressively reduced until 49 d of age (d 0$)$, when calves were completely weaned. From 21 to 49 d of age an automated milk replacer feeder recorded individual replacer intake. At $63 \mathrm{~d}$ of age, calves were moved to an open lot with capacity for approximately 60 calves. Calves had ad libitum access 
Table 1. Milk replacer and concentrate for starter feedlot compositions

\begin{tabular}{lcc}
\hline Nutrient & $\begin{array}{c}\text { Milk } \\
\text { replacer }\end{array}$ & $\begin{array}{c}\text { Concentrate } \\
\text { starter }\end{array}$ \\
\hline $\mathrm{CP}, \%$ & 28 & 12 \\
Crude fat, \% & 15 & 1 \\
Crude fiber, \% & 0.15 & 26 \\
$\mathrm{Ca}, \%$ & $>0.9,<1.1$ & $>0.45,<0.95$ \\
$\mathrm{P}, \%$ & $>0.7$ & $>0.4$ \\
$\mathrm{~K}, \%$ & - & $>1.10$ \\
$\mathrm{NaCl}, \mathrm{IU} / \mathrm{kg}$ & - & $>0.25,<0.75$ \\
Vitamin A, IU/kg & $>66,000$ & 5,000 \\
Vitamin $\mathrm{D}_{3}, \mathrm{IU} / \mathrm{kg}$ & $>11,000$ & - \\
Vitamin E, IU $/ \mathrm{kg}$ & $>166$ & 70 \\
Chlortetracycline, $\mathrm{mg} / \mathrm{kg}$ & - & 70 \\
Sulfamethazine, $\mathrm{mg} / \mathrm{kg}$ & - & \\
\hline
\end{tabular}

to starter, water, and mineral salt blocks starting at $24 \mathrm{~h}$ after birth. The chemical compositions of milk replacer and starter are described in Table 1. The study activities are depicted in Figure 1.

\section{Treatments}

Calves $(\mathrm{n}=36)$ were enrolled in the experiment on 3 consecutive days of the same week. Within each enrollment day, calves were paired for serum total protein 48 $\mathrm{h}$ after birth and ADG from birth to enrollment. Calves were allocated randomly to the control and rbST treatment. Calves assigned to the control treatment $(\mathrm{n}=$ 18) were treated weekly with $0.5 \mathrm{~mL}$ of $0.9 \%$ of saline solution (saline solution 0.9\%, Valley Vet Supply, Marysville, KS), subcutaneously in the neck area, from 21 to $63 \mathrm{~d}$ of age. Calves assigned to the rbST treatment $(\mathrm{n}=18)$ were treated with $1.5 \mathrm{mg}$ (21 to $35 \mathrm{~d}$ of age) and $1.8 \mathrm{mg}$ (42 to $63 \mathrm{~d}$ of age) of rbST (Posilac, Elanco Animal Health, Greenfield, IN) per kg of BW, subcutaneously in the neck area. Injections of saline and rbST were given in alternate sides of the neck area to prevent iatrogenic lesions of the neck. Injections were given using 1-mL tuberculin syringes and hypodermic $1.29-\mathrm{mm}$ thickness and $1.6 \mathrm{~cm}$-long needles. On the day before treatment with $\mathrm{rbST}$, the rbST contained in commercially available ready-to-use syringes of rbST (Posilac, Elanco Animal Health) were dispensed into sterile containers and the appropriate volume of rbST was aspirated into sterile syringes that were kept refrigerated until treatment of calves on farm. The dose of rbST was chosen based on a pilot experiment with eight 21-d-old calves that, under the same management conditions as the calves used in this experiment, were treated with 0 to $5 \mathrm{mg}$ of $\mathrm{rbST} / \mathrm{kg}$ of BW. The resulting increase in IGF-1 concentration was linear. In previous experiments from our group, rbST-induced increases in GH and IGF-1 concentrations of approximately 30\% above the concentrations of untreated cows resulted in improvements in PMN function and concentration of anti-ovalbumin IgG in serum (Silva et al., 2015).

\section{Blood Samples}

Blood was sampled at $-28,-25,-21,-11,0$ (49 d of age), 3,7 , and $14 \mathrm{~d}$ relative to weaning date by jugular venipuncture. In total, approximately $23 \mathrm{~mL}$ of blood was sampled each day, 2 samples in $10-\mathrm{mL}$ evacuated tubes containing Heparin (Vacutainer Systems, Becton Dickinson, Franklin Lakes, NJ), one sample in a 10$\mathrm{mL}$ evacuated tube without anticoagulant (Vacutainer Systems, Becton Dickinson), and one sample in a 3-mL evacuated tube containing EDTA (Vacutainer Systems, Becton Dickinson). Whole-blood heparinized samples were used for PMN function and granulocytes, lymphocyte, and CD14+ monocyte adhesion molecule assays. Plasma was used to determine the concentrations of

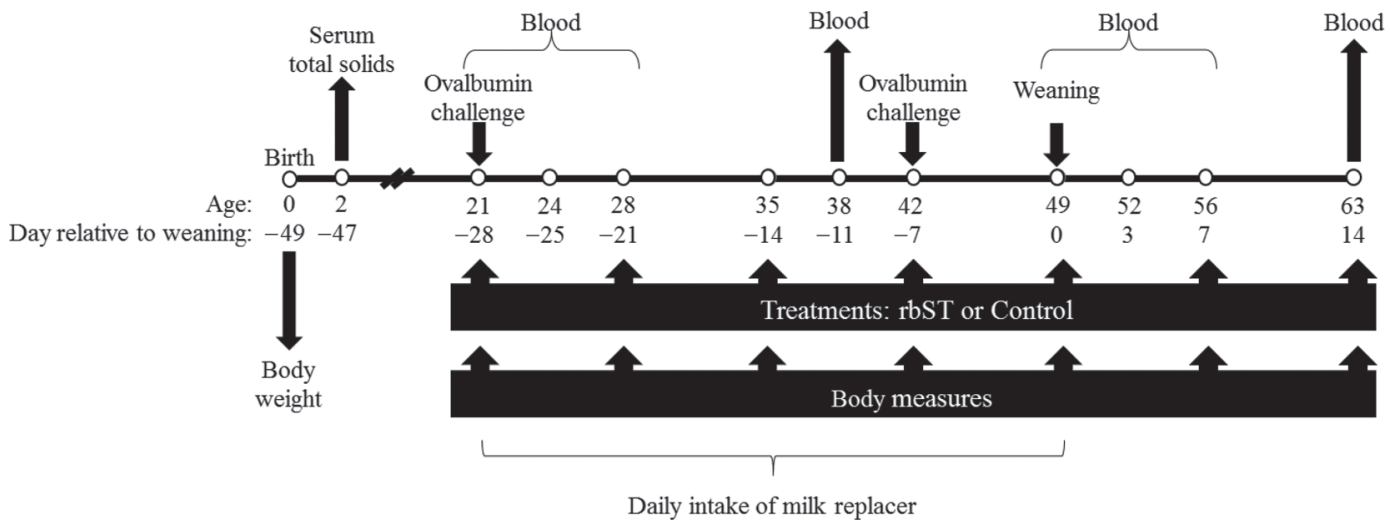

Figure 1. Schematic depiction of study design. Control = calves received injections with saline (saline solution $0.9 \%$, Valley Vet Supply, Marysville, KS); rbST = calves received 1.5 to $1.8 \mathrm{mg} / \mathrm{kg}$ of recombinant bST (Posilac, Elanco Animal Health, Greenfield, IN) every $7 \mathrm{~d}$ from 21 to 63 d of life. 
GH, insulin, IGF-1, and haptoglobin. Serum was used to determine the concentrations of anti-ovalbumin IgG, glucose, fatty acids, and BHB. Samples collected in the 3-mL tubes containing EDTA were used for complete hemogram.

Tubes without anticoagulant were placed in ice immediately after sample collection. Heparinized tubes were kept at room temperature in a cooler without ice, protected from light, until the whole-blood for the PMN function and adhesion molecule assays was apportioned within $2 \mathrm{~h}$ after sampling. Similarly, EDTA tubes were also kept at room temperature, in a cooler without ice, until hemogram was assessed within $2 \mathrm{~h}$ of sample collection. Tubes were centrifuged at 3,000 $\times$ $g$ for $10 \mathrm{~min}$ at $4^{\circ} \mathrm{C}$ for plasma and serum separation. Eight aliquots were separated into 1.5-mL microcentrifuge tubes (Eppendorf, Enfield, CT) and kept frozen at $-80^{\circ} \mathrm{C}$ until analysis.

\section{Innate Immune Parameters and Hemogram}

The procedures described herein have been reported previously (Martinez et al., 2012; Silva et al., 2016; Moraes et al., 2017; Vieira-Neto et al., 2017). Blood samples collected with $\mathrm{K}_{2}$ EDTA tubes were analyzed within $2 \mathrm{~h}$ after sampling using a Procyte hematology analyzer (Idexx Laboratories, Westbrook, ME) for complete hemogram. Polymorphonuclear leukocyte activity was determined following a challenge of the whole-blood with intrauterine pathogenic E. coli (IUPEC, KCJ852) labeled with propidium iodide. Whole-blood $(100 \mu \mathrm{L})$ was incubated with $10 \mu \mathrm{L}$ of dihydrorhodamine 123 (Sigma-Aldrich, St. Louis, MO), a free radical sensor, at $37^{\circ} \mathrm{C}$ for $10 \mathrm{~min}$. According to the individual's neutrophil count based on the hemogram, E. coli was added to the samples to result in a bacterium-to-neutrophil ratio of 40:1, and samples were incubated for $30 \mathrm{~min}$ at $37^{\circ} \mathrm{C}$. Thereafter, samples were kept on ice until the addition of trypan blue solution (Sigma-Aldrich) to quench autofluorescence. Phagocytosis was determined by measurement of propidium iodide fluorescence emissions at $670 \mathrm{~nm}$ and oxidative burst was determined by measurement of dihydrorhodamine 123 fluorescence emissions at $533 \mathrm{~nm}$ using a BD Acccuri C6 (BD Biosciences, San Jose, CA) flow cytometer equipped with 488- and $640-n m$ lasers. Flow cytometry compensation settings were determined using $E$. coli that were not labeled with propidium iodide. Neutrophils were identified according to their size and granularity using forward- and side-scatter detectors, and data from 10,000 cells per sample were analyzed using Flowjo software (version 7.6.5., Tree Star Inc., Ashland, OR).
Leukocyte surface proteins were labeled with antibodies to CD14 (Tuk4 clone conjugated to PE-Cy5.5, MHCD1418, Thermo Fisher Scientific, Waltham, MA), CD18 (BAQ30A clone, Washington State University, Pullman, WA, conjugated to Alexa 488, Thermo Fisher Scientific) and L-selectin (CD62L; BAQ92A clone, Washington State University, Pullman, WA, conjugated to R-phycoerythrin, Abcam, Cambridge, MA). Briefly, erythrocytes were removed by hypotonic lysis followed by centrifugation at $450 \times g$ for 5 min at room temperature. Leukocytes were resuspended in $50 \mu \mathrm{L}$ of antibody cocktail containing each antibody diluted 1:100 in PBS with $0.5 \% \mathrm{BSA}$ and $2 \mathrm{~m} M$ EDTA (both from Thermo Fisher Scientific). Cells were incubated on ice for $30 \mathrm{~min}$, then washed with $2 \mathrm{~mL}$ of PBS followed by centrifugation at $650 \times g$ for $5 \mathrm{~min}$ at room temperature. Cells were analyzed (10,000 cells/sample) on a BD Accuri 6 (BD Biosciences) flow cytometer equipped with 488- and 640-nm lasers. Flow cytometry data were analyzed using Flowjo software (version7.6.5, Tree Star Inc.). Lymphocytes, granulocytes, and monocytes were gated on the basis of size, granularity, and CD14 expression, in which CD14+ mononuclear cells were considered monocytes. Data referent to phagocytosis, oxidative burst, CD18, and CD62L are expressed as median fluorescence intensity.

\section{Ovalbumin Vaccination and Concentration of Anti-Ovalbumin IgG}

Calves received 2 injections of $0.5 \mathrm{mg}$ of chicken egg albumin (Type VII, Sigma-Aldrich), diluted in $0.5 \mathrm{~mL}$ of PBS and emulsified in $0.5 \mathrm{mg}$ of adjuvant Quil-A (Accurate Chemical \& Scientific Corporation, Westbury, NY), previously diluted in $0.5 \mathrm{~mL}$ of PBS. The immunization was performed by subcutaneous injection in the neck area at 21 and $42 \mathrm{~d}$ of age using $1-\mathrm{mL}$ tuberculin syringes and hypodermic needles $(1.29 \mathrm{~mm}$ thick and $1.6 \mathrm{~cm} \mathrm{long).}$

Concentration of anti-ovalbumin IgG was determined by ELISA. Wells were coated overnight with ovalbumin protein (\#A5503; Sigma-Aldrich), diluted in 0.1 $M$ carbonate-bicarbonate coating buffer $(1.6 \mathrm{mg} / \mathrm{L}$ of ovalbumin, $\mathrm{pH} 9.4$ ). Wells were washed with Tris-buffered saline $(0.9 \%)$ with $0.05 \%$ Tween 20 and blocked for $2 \mathrm{~h}$ with $4 \%$ BSA diluted in PBS (pH 7.4). Samples, diluted 1:50 in Tris-buffered saline, were added and incubated at room temperature for $1 \mathrm{~h}$. Horseradish peroxidase-conjugated detection antibody produced in sheep against bovine IgG heavy chain (\#A10-118P; Bethyl Laboratories, Montgomery, TX) was diluted in Tris-buffered saline, added to each well, and incubated for $1 \mathrm{~h}$. Each well was washed 3 times and 
3,3',5,5'-tetramethylbenzidine ELISA peroxidase substrate (Rockland Immunochemicals Inc., Gilbertsville, PA) was added to each well and allowed to react for 20 min. The enzyme reaction was ended by adding $0.2 \mathrm{M}$ sulfuric acid, and absorbance was read at a wavelength of $450 \mathrm{~nm}$ (Victor 3 Multi-label Counter model 1420; PerkinElmer Life Sciences, Waltham, MA). Detection antibody was diluted in Tris-buffered saline and it was empirically determined that a 1:7,500 dilution resulted in the greatest signal-to-noise ratio. Mean coefficients of variation for total IgG and ovalbumin-specific $\operatorname{IgG}$ assays for plasma were 4 and $3.6 \%$, respectively.

\section{Hormone Analysis}

Serum concentrations of GH were determined in duplicate in all samples by RIA using procedures described by Klindt et al. (1983). Bovine GH (AFP9884C, National Hormone and Pituitary Program, Los Angeles, CA) was used as the radioiodinated antigen and standard. Growth hormone antisera (AFPB55, National Hormone and Pituitary Program) was used at an initial dilution of 1:200,000. Inhibition curves of sera ranging from 50 to $400 \mathrm{~mL}$ were parallel to standard curves. Sensitivity of the assay was $19.9 \mathrm{pg} / \mathrm{mL}$ and the intra- and interassay coefficients of variation were 7.3 and $8.1 \%$, respectively.

Concentrations of insulin were determined using a commercial ELISA kit (Mercodia Bovine Insulin ELISA, Mercodia AB, Winston-Salem, NC). Total IGF-1 concentrations were determined using a commercial ELISA kit (Quantikine ELISA Human IGF-1 immunoassay; R\&D Systems, Minneapolis, MN) with $100 \%$ cross reactivity with bovine IGF-1.

\section{Concentrations of Metabolites and Haptoglobin}

Serum concentrations of fatty acid, BHB, and glucose were measured using the RX Daytona bench clinical chemistry analyzer using commercial kits (Randox Laboratories Ltd., Crumlin, UK). Plasma haptoglobin concentrations were determined by measuring haptoglobin/hemoglobin complex by the estimation of difference in peroxidase activity (Hulbert et al., 2011b; Cooke and Arthington, 2013), and optical density was measured by a plate reader at $410 \mathrm{~nm}$ (Power Wave XS, BioTek, Winooski, VT). Results are described in absorbance multiplied by 100 .

\section{Body Weight and Wither Height}

Body weight was determined at birth, and at -29 , $-24,-20,-10,-1,2,6$, and $13 \mathrm{~d}$ relative to weaning using an electronic scale that was calibrated at the start of the experiment. Wither height was determined at $-29,-24,-20,-10,-1,2,6$, and 13 d relative to weaning with a metric tape by the same person with the animal standing on plain hard soil.

\section{Statistical Analysis}

All statistical analyses were performed with SAS (9.3 SAS Institute Inc., Cary, NC). Continuous variables were analyzed by ANOVA using the GLM procedure for pretreatment values (baseline) and the MIXED procedure for repeated measures. The statistical models to compare baseline values between treatments included treatment and enrollment weight. The statistical models to evaluate the effects of treatment on repeated measure data (e.g., hormones of the somatotropic axis, immune parameters, metabolites, milk replacer intake, and ADG) included treatment, day, the interaction between treatment and day, baseline value for the variable being analyzed, and enrollment weight. Calf was used as the random effect and was nested within treatment. Covariates with $P \geq 0.15$ were removed manually in a stepwise manner. Residuals were tested for normality and when normality was not met the dependent variable was transformed $(\log 10$ or square root). The following data were $\log 10$ transformed for statistical analysis: intensity of phagocytosis by PMN; intensity of expression of CD62L and CD18 by granulocytes, lymphocytes, and CD14+ monocytes; leukocyte and neutrophil counts; and insulin, IGF-1, and BHB concentrations. Intensity of oxidative burst data were square root transformed. All data presented are referent to raw values. Concentrations of haptoglobin from -24 to $0 \mathrm{~d}$ relative to weaning, at $3 \mathrm{~d}$ after weaning, and at 7 and $14 \mathrm{~d}$ after weaning were analyzed separately. Statistical significance was considered at $P \leq 0.05$ and tendency for statistical significance at $0.05<P \leq 0.15$.

\section{RESULTS}

We found no differences between treatments regarding BW at birth (control $=43.8 \pm 1.5 \mathrm{~kg}, \mathrm{rbST}=42.8$ $\pm 1.5 \mathrm{~kg} ; P=0.65)$, BW at enrollment (control $=52.5$ $\pm 1.9 \mathrm{~kg}, \mathrm{rbST}=53.1 \pm 1.9 \mathrm{~kg} ; P=0.83)$, and wither height at enrollment (control $=80.4 \pm 0.6 \mathrm{~cm}, \mathrm{rbST}=$ $81.5 \pm 0.6 \mathrm{~cm} ; P=0.22)$.

\section{Effects of Treatment on Somatotropic Axis}

At enrollment, we observed no $(P=0.58)$ difference between treatments in GH concentration (Figure 2A). The interaction between treatment and day affected $(P$ $=0.01)$ the $\mathrm{GH}$ concentration because on $\mathrm{d}-25,-11$, 3,7 , and 14 relative to weaning $\mathrm{GH}$ concentrations were 
greater in rbST-treated calves compared with control calves (Figure $2 \mathrm{~A})$. At enrollment, no $(P=0.73)$ difference was noted between treatments regarding IGF-1 concentration (Figure 2B). We observed a tendency $(P$ $=0.08$ ) for the interaction between treatment and day to affect the concentration of IGF-1. Despite the fact that at $-25,-21,-11,0,3,7$, and $14 \mathrm{~d}$ relative to weaning IGF-1 concentrations of rbST-treated calves were $(P<0.05)$ greater than control calves, differences were greatest at $-11 \mathrm{~d}$ relative to weaning (Figure 2B). Insulin concentration at enrollment was not $(P=0.55)$ different between treatments. Treatment did not $(P=$ 0.42 ) affect concentrations of insulin from $d-25$ to 14 relative to weaning (Figure $2 \mathrm{C}$ ).

\section{Effects of Treatment on PMN Function, Expression of Adhesion Molecules, and Concentrations of Anti-Ovalbumin IgG and Haptoglobin}

At enrollment, we did not observe differences between treatments regarding intensity of phagocytosis $(P=0.25)$ and oxidative burst $(P=0.77)$ by PMN or percentage of PMN positive for phagocytosis and oxidative burst $(P=0.50)$. Treatment did not affect the intensity of phagocytosis $(P=0.74$; Figure $3 \mathrm{~A})$ and oxidative burst $(P=0.71$; Figure $3 \mathrm{~B})$ by PMN. Additionally, treatment did not affect the percentage of PMN positive for phagocytosis and oxidative burst $(P$ $=0.59$; Figure $3 \mathrm{C}$ ).

At enrollment, no differences were noted between treatments regarding the intensity of expression of CD62L $(P=0.14)$ and $\mathrm{CD} 18(P=0.18)$ by granulocytes, expression of CD62L $(P=0.38)$ and CD18 $(P$ $=0.53)$ by lymphocytes, and expression of CD62L $(P$ $=0.93)$ and $\operatorname{CD} 18(P=0.46)$ by CD14+ monocytes. Treatment with rbST tended to increase the intensity of expression of CD62L $(P=0.06$; Figure $4 \mathrm{~A})$ and CD18 $(P=0.07$; Figure $4 \mathrm{~B})$ by granulocytes from $\mathrm{d}$ -25 to 14 relative to weaning. Intensity of expression of CD62L by lymphocytes from $\mathrm{d}-25$ to 14 relative to weaning tended $(P=0.13$; Figure $4 \mathrm{C})$ to be affected by treatment, but intensity of expression of CD18 $(P=$ 0.18 ; Figure 4D) was not affected by treatment. Treatment with rbST did not affect the intensity of expression of CD62L $(P=0.86$; Figure $4 \mathrm{E})$ and $\mathrm{CD} 18(P=$ 0.95; Figure $4 \mathrm{~F}$ ) by CD14+ monocyte.

The concentration of anti-ovalbumin IgG at enrollment was not $(P=0.68)$ different between treatments. Additionally, rbST treatment $(P=0.75)$ and the interaction between treatment and day relative to weaning $(P=0.28)$ did not affect the concentration of anti-ovalbumin IgG (Figure 5). Day relative to weaning was $(P<0.01)$ associated with the concentration of anti-ovalbumin IgG because $17 \mathrm{~d}$ after the first immu-
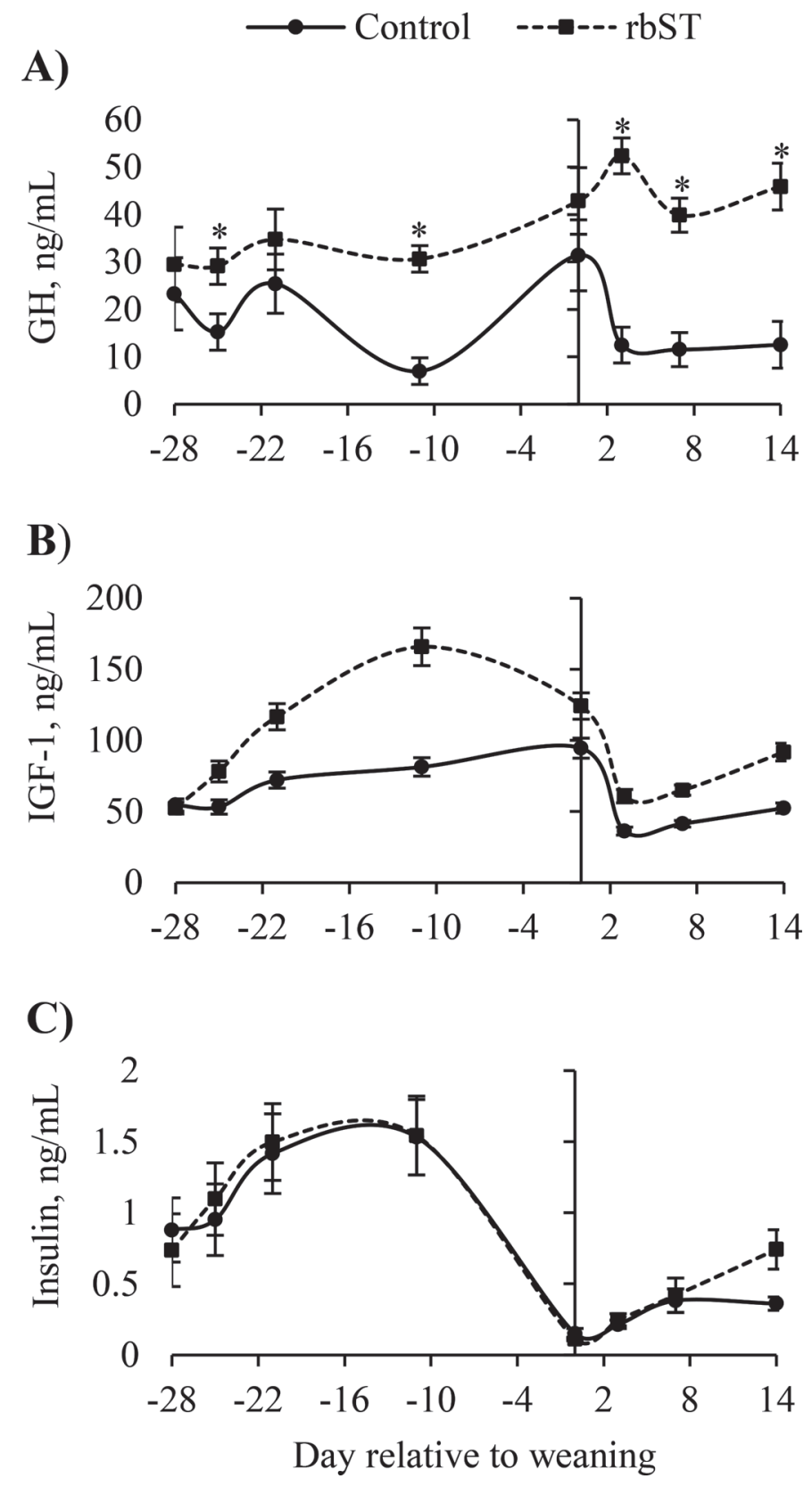

Figure 2. Effect of recombinant (r)bST treatment on concentrations of (A) growth hormone, (B) IGF-1, and (C) insulin. Control $=$ calves received injections with saline (saline solution $0.9 \%$, Valley Vet Supply, Marysville, KS); rbST = calves received 1.5 to $1.8 \mathrm{mg} /$ $\mathrm{kg}$ of rbST (Posilac, Elanco Animal Health, Greenfield, IN) every 7 d from 21 to $63 \mathrm{~d}$ of life. At enrollment, we observed no differences between treatments in $\mathrm{GH}(P=0.58)$, IGF-1 $(P=0.73)$, or insulin $(P$ $=0.55)$ concentration. Growth hormone: treatment $(P<0.01)$, day $(P<0.01)$, and interaction between treatment and day $(P=0.01)$. Insulin-like growth factor-1: treatment $(P=0.01)$, day $(P<0.01)$, and interaction between treatment and day $(P=0.08)$. Insulin: treatment $(P=0.42)$, day $(P<0.01)$, and interaction between treatment and day $(P=0.31)$. ${ }^{*}$ Within day, means with an asterisk differ $(P \leq 0.05)$. Error bars represent the SEM. 


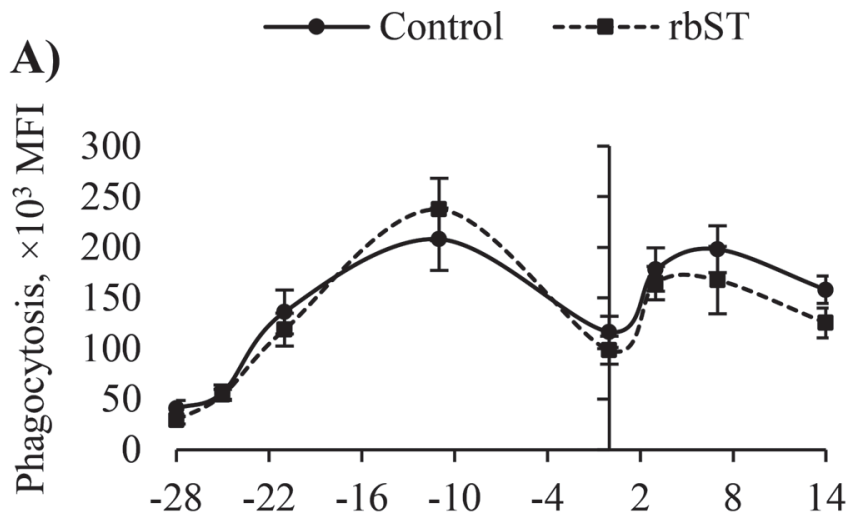

B)

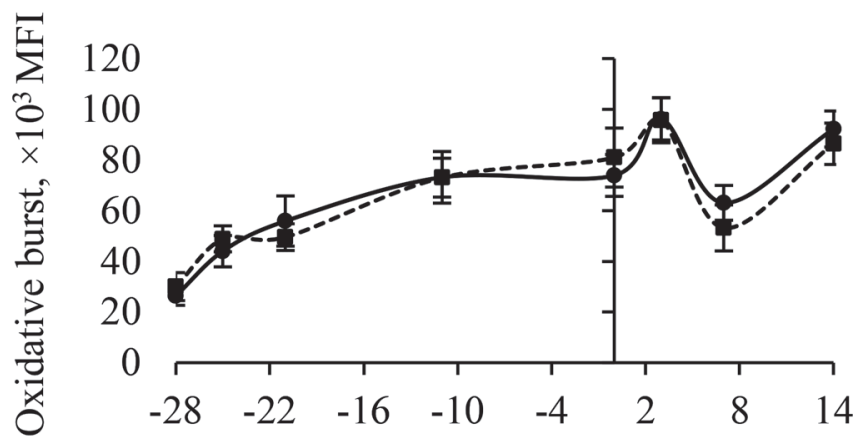

C)

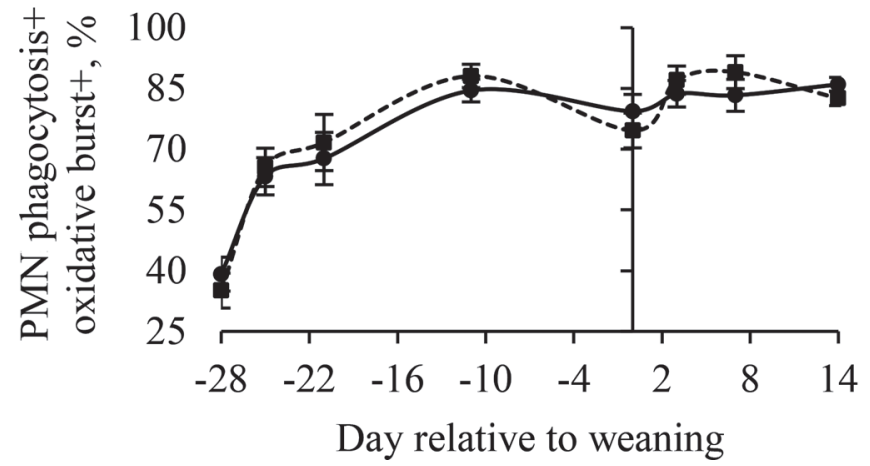

Figure 3. Effects of recombinant (r)bST treatment on (A) PMN intensity of phagocytosis, (B) PMN intensity of oxidative burst, and (C) percentage of PMN positive for phagocytosis and oxidative burst. Control $=$ calves received injections with saline (saline solution $0.9 \%$, Valley Vet Supply, Marysville, KS); rbST = calves received 1.5 to 1.8 $\mathrm{mg} / \mathrm{kg}$ of rbST (Posilac, Elanco Animal Health, Greenfield, IN) every $7 \mathrm{~d}$ from 21 to $63 \mathrm{~d}$ of life. At enrollment, we found no differences between treatments regarding intensity of phagocytosis $(P=0.25)$ and oxidative burst $(P=0.77)$ by PMN and percentage of PMN positive for phagocytosis and oxidative burst $(P=0.50)$. Intensity of phagocytosis: treatment $(P=0.74)$, day $(P<0.01)$, and interaction between treatment and day $(P=0.75)$. Intensity of oxidative burst: treatment $(P=0.71)$, day $(P<0.01)$, and interaction between treatment and day $(P=0.36)$. Percentage of PMN positive for phagocytosis and oxidative burst: treatment $(P=0.59)$, day $(P<0.01)$, and interaction between treatment and day $(P=0.57)$. Error bars represent the SEM. MFI $=$ median fluorescence intensity. nization ( $\mathrm{d}-11$ relative to weaning) the concentration of anti-ovalbumin IgG had increased by $215 \%$ over the baseline, and $7 \mathrm{~d}$ after the second immunization (d 0 relative to weaning) the concentration of antiovalbumin IgG had increased by $557 \%$ over the baseline (Figure 5). Haptoglobin concentration at enrollment was not $(P=0.31)$ different between treatment (Figure $6)$. From -25 to $0 \mathrm{~d}$ relative to weaning treatment did not $(P=0.77)$ affect haptoglobin concentration, but on $\mathrm{d} 3$ relative to weaning rbST calves had $(P=0.04)$ reduced haptoglobin concentration compared with control calves. From 7 to $14 \mathrm{~d}$ relative to calving, we found no $(P=0.56)$ differences in haptoglobin concentration between treatments (Figure 6).

\section{Effects of Treatment on Hemogram Parameters and Metabolites}

Results of the hemogram are described in Table 2. At enrollment, rbST calves had $(P=0.05)$ reduced leukocyte count and tended to have reduced lymphocyte $(P$ $=0.09)$ and granulocyte $(P=0.11)$ counts compared with control calves. Calves treated with rbST tended $(P=0.07)$ to have reduced hematocrit from $\mathrm{d}-25$ to 14 relative to weaning. The interaction between treatment and day relative to weaning affected $(P=0.05)$ the platelet count from $\mathrm{d}-25$ to 14 relative to weaning, because $3 \mathrm{~d}$ after weaning rbST-treated calves tended $(P=0.10)$ to have greater platelet count than control calves $\left(551.7 \pm 32.6\right.$ vs. $\left.470.2 \pm 34.5 \times 10^{3} / \mu \mathrm{L}\right)$. No other effects of rbST treatment on hemogram parameters were observed.

At enrollment, we observed no differences between treatments regarding concentrations of glucose $(P=$ $0.87)$, fatty acids $(P=0.22)$, and BHB $(P=0.56)$. We found a tendency $(P=0.07)$ for the interaction between treatment and day relative to weaning to affect glucose concentration from -25 to $14 \mathrm{~d}$ relative to weaning (Figure 7A), because on $\mathrm{d}-11$ relative to weaning rbST-treated calves had $(P=0.03)$ greater glucose concentration than control calves $(144.2 \pm 6.6$ vs. $123.8 \pm 6.6 \mathrm{ng} / \mathrm{dL})$. Treatment did not affect the concentrations of fatty acids $(P=0.97)$ and $\operatorname{BHB}(P=$ 0.28 ) from -25 to $14 \mathrm{~d}$ relative to weaning (Figure $7 \mathrm{~B}$ and $7 \mathrm{C}$, respectively).

\section{Effects of Treatment on BW, Wither Height, ADG, and Milk Replacer Consumption}

Calves treated with $\operatorname{rbST}$ had $(P=0.02)$ reduced intake of milk replacer from $\mathrm{d}-28$ to 0 relative to weaning $(7.2 \pm 0.3$ vs. $8.1 \pm 0.3 \mathrm{~L} / \mathrm{d})$. The interaction between treatment and day relative to weaning did not $(P=0.50)$ affect milk replacer intake (Figure 
$8 \mathrm{~A})$. Treatment did not $(P=0.81)$ affect the live $\mathrm{BW}$ $($ control $=75.8 \pm 1.2, \operatorname{rbST}=75.4 \pm 1.2 \mathrm{~kg})$ from $\mathrm{d}$ -24 to 13 relative to weaning (Figure 8B). Similarly, we noted no $(P=0.55)$ difference in ADG from $\mathrm{d}-24$ to 14 relative to weaning between control $(833.0 \pm 41.1$ $\mathrm{g} / \mathrm{d})$ and $\operatorname{rbST}(797.9 \pm 41.1 \mathrm{~g} / \mathrm{d})$ calves.

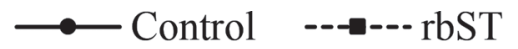

A)

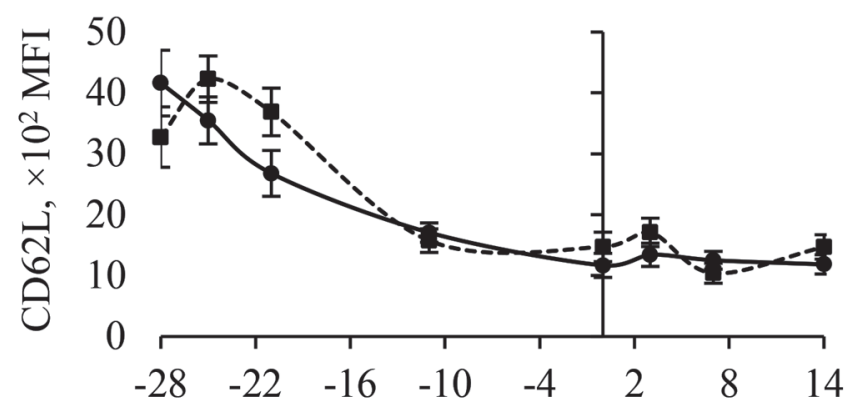

B)

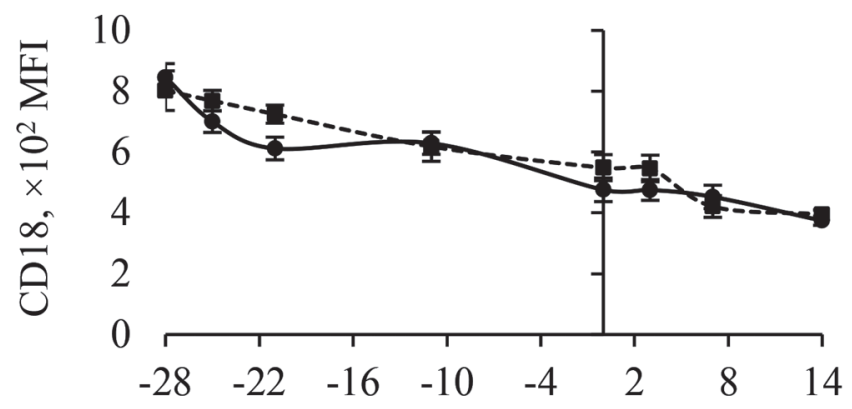

C)

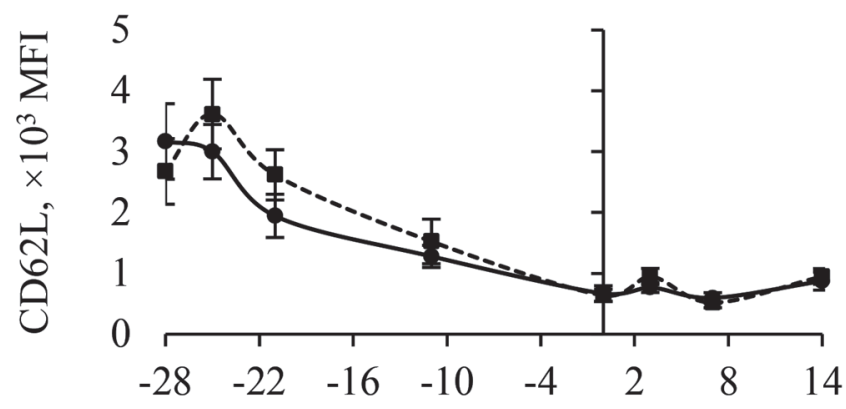

Day relative to weaning
D)

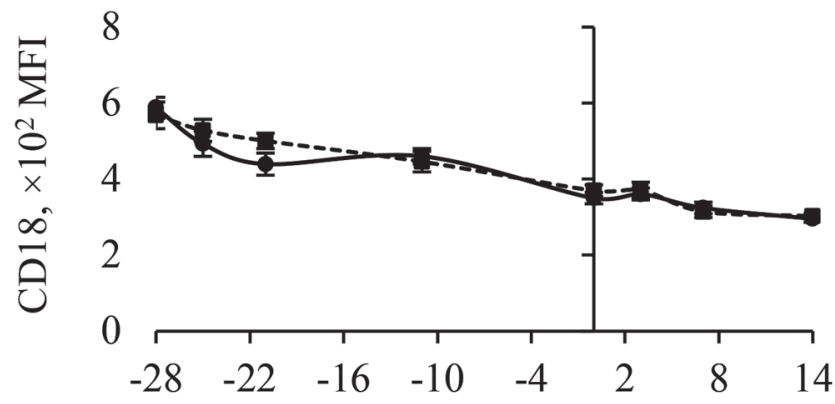

E)

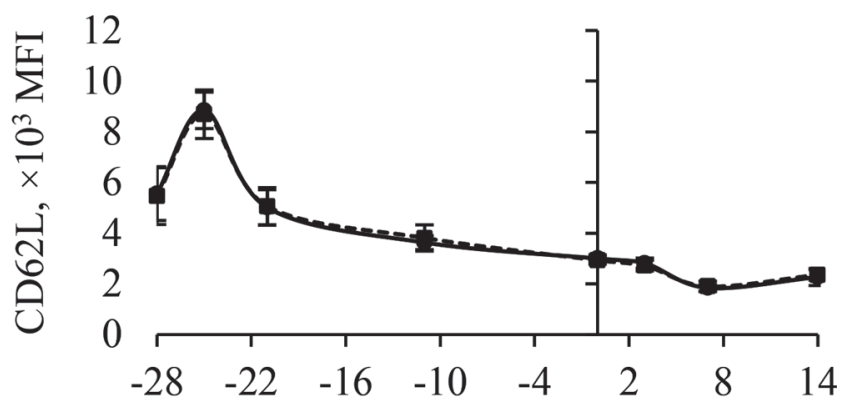

F)

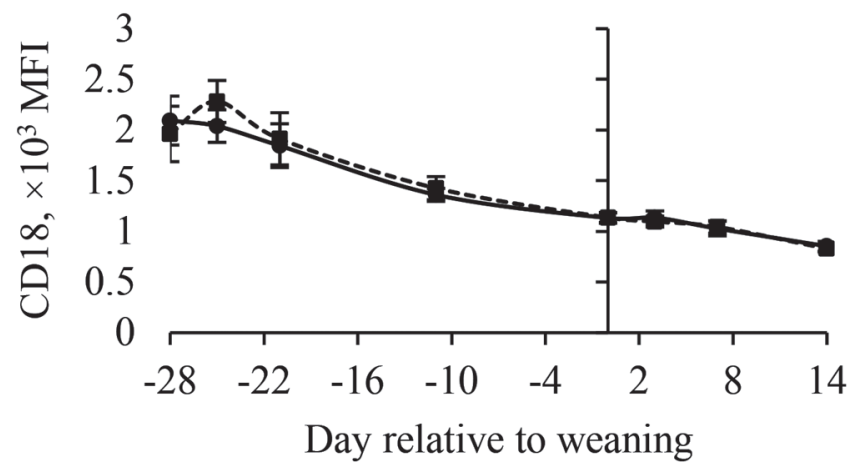

Figure 4. Effect of recombinant (r)bST treatment on intensity of expression of L-selectin (CD62L) and CD18, respectively, by (A and B) granulocytes, $(\mathrm{C}$ and $\mathrm{D})$ lymphocytes, and $(\mathrm{E}$ and $\mathrm{F}) \mathrm{CD} 14+$ monocytes. Control $=$ calves received injections with saline (saline solution $0.9 \%$, Valley Vet Supply, Marysville, KS); rbST = calves received 1.5 to $1.8 \mathrm{mg} / \mathrm{kg}$ of rbST (Posilac, Elanco Animal Health, Greenfield, IN) every $7 \mathrm{~d}$ from 21 to $63 \mathrm{~d}$ of life. At enrollment, we found no differences between treatments regarding the intensity of expression of CD62L $(P=0.14)$ and CD18 $(P=0.18)$ by granulocytes, expression of CD62L $(P=0.38)$ and CD18 $(P=0.53)$ by lymphocytes, and expression of CD62L $(P=0.93)$ and CD18 $(P=0.46)$ by CD14+ monocytes. Granulocyte CD62L: treatment $(P=0.06)$, day $(P<0.01)$, and interaction between treatment and day $(P=0.15)$. Granulocyte CD18: treatment $(P=0.07)$, day $(P<0.01)$, and interaction between treatment and day $(P=0.34)$. Lymphocyte CD62L: treatment $(P=0.13)$, day $(P<0.01)$, and interaction between treatment and day $(P=0.58)$. Lymphocyte CD18: treatment $(P=$ $0.18)$, day $(P<0.01)$, and interaction between treatment and day $(P=0.57)$. CD14+ monocyte CD62L: treatment $(P=0.86)$, day $(P<0.01)$, and interaction between treatment and day $(P=1.00)$. CD14+ monocyte CD18: treatment $(P=0.95)$, day $(P<0.01)$, and interaction between treatment and day $(P=0.99)$. Error bars represent the SEM. MFI = median fluorescence intensity. 


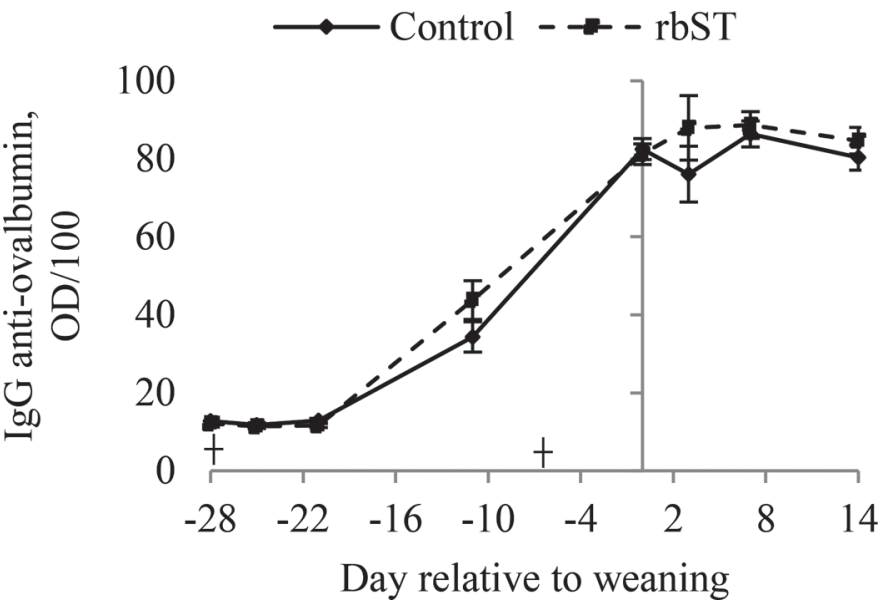

Figure 5. Effect of recombinant (r)bST treatment on concentration of anti-ovalbumin IgG. Control = calves received injections with saline (saline solution $0.9 \%$, Valley Vet Supply, Marysville, KS); rbST = calves received 1.5 to $1.8 \mathrm{mg} / \mathrm{kg}$ of rbST (Posilac, Elanco Animal Health, Greenfield, IN) every $7 \mathrm{~d}$ from 21 to $63 \mathrm{~d}$ of life. We found no $(P=0.68)$ difference between treatments regarding the concentration of anti-ovalbumin IgG at enrollment. Day -25 to 14 : treatment $(P$ $=0.75)$, day $(P<0.01)$, and interaction between treatment and day $(P=0.28)$. Error bars represent the SEM. The cross represents time when injections of $0.5 \mathrm{mg}$ of chicken egg albumin (Type VII, SigmaAldrich Co., St. Louis, MO) were administered. OD = optical density.

\section{DISCUSSION}

The current experiment evaluated the use of rbST as an immunomodulatory drug because of the resulting increase in $\mathrm{GH}$ concentration and $\mathrm{GH}$-induced increase in IGF-1 concentration. As expected, rbST-treated calves had significantly higher GH and IGF-1 concentrations compared with control calves throughout the experiment. The weaning-associated energy deficit was associated with a $62 \%$ decrease in IGF-1 concentration from d 0 to 3 relative to weaning among control calves. Unexpectedly, rbST-treated calves had a similar decrease in IGF-1 concentration $(62 \%)$ from $d-11$ to 3 relative to weaning. This leads us to speculate that

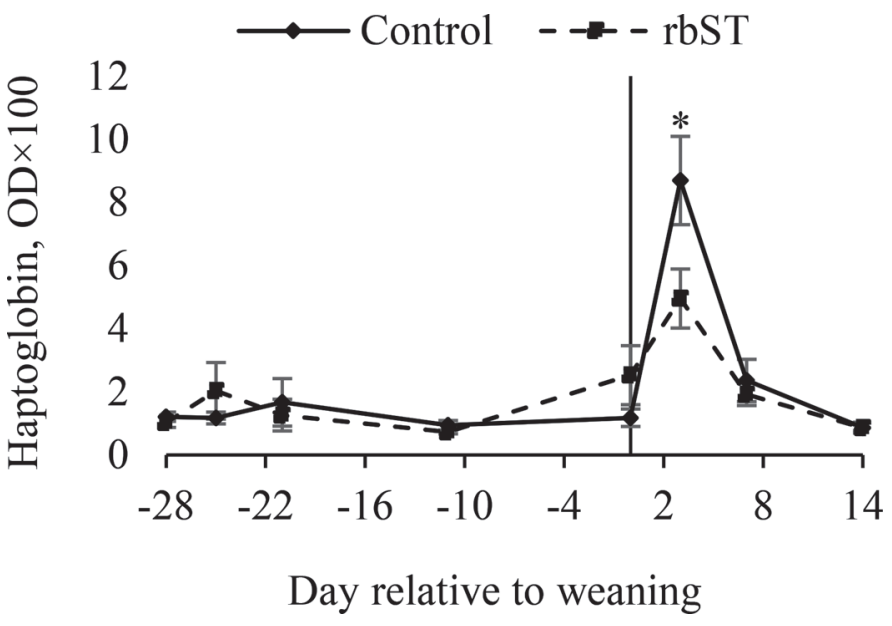

Figure 6. Effect of recombinant (r)bST treatment on haptoglobin concentration. Control $=$ calves received injections with saline $($ saline solution $0.9 \%$, Valley Vet Supply, Marysville, KS); rbST $=$ calves received 1.5 to $1.8 \mathrm{mg} / \mathrm{kg}$ of $\mathrm{rbST}$ (Posilac, Elanco Animal Health, Greenfield, IN) every $7 \mathrm{~d}$ from 21 to $63 \mathrm{~d}$ of life. At enrollment, concentration of haptoglobin was not $(P=0.31)$ different between treatments. Day -25 to 0 relative to weaning: treatment $(P=0.77)$, day $(P=0.18)$, and interaction between treatment and day $(P=0.52)$. Day 3 relative to weaning: treatment $\left({ }^{*} P=0.04\right)$. Day 7 to 14 relative to weaning: treatment $(P=0.56)$, day $(P=0.24)$, and interaction between treatment and day $(P=0.33)$. Error bars represent the SEM.

the metabolic challenges faced by the calves in the current experiment, demonstrated by the abrupt decreases in glucose and insulin concentrations and increases in fatty acid and BHB concentrations around weaning, were sufficient to cause uncoupling of the somatotropic axis. In a series of experiments with periparturient dairy cows, Silva et al. $(2015,2017 \mathrm{a})$ demonstrated that rbST treatment increased GH concentration throughout the periparturient period, whereas rbST-induced increase in IGF-1 concentration was mainly observed prepartum and again only at approximately 21 to $28 \mathrm{~d}$ postpartum. The uncoupling of the somatotropic axis, characterized by the downregulation of hepatic GH-1 $\alpha$

Table 2. Effect of recombinant bST treatment on hemogram parameters

\begin{tabular}{|c|c|c|c|c|c|c|c|c|}
\hline \multirow[b]{2}{*}{ Item $( \pm$ SEM $)$} & \multicolumn{2}{|c|}{ Enrollment $(-28 \mathrm{~d})^{1}$} & \multirow[b]{2}{*}{$P$-value } & \multicolumn{2}{|c|}{-25 to $14 \mathrm{~d}$ relative to weaning ${ }^{1}$} & \multicolumn{3}{|c|}{$P$-value } \\
\hline & Control $^{1}$ & $\operatorname{rbST}^{1}$ & & Control $^{1}$ & $\operatorname{rbST}^{1}$ & $\operatorname{Trt}^{1}$ & Day & Trt $\times$ Day \\
\hline Hematocrit, $\%$ & $32.6 \pm 1.4$ & $31.5 \pm 1.3$ & 0.57 & $35.3 \pm 0.7$ & $33.5 \pm 0.6$ & 0.07 & $<0.01$ & 0.23 \\
\hline Hemoglobin, g/dL & $7.7 \pm 0.9$ & $7.9 \pm 0.9$ & 0.86 & $3.3 \pm 0.08$ & $3.2 \pm 0.08$ & 0.46 & $<0.01$ & 0.97 \\
\hline Red blood cell, $\times 10^{6} / \mu \mathrm{L}$ & $8.4 \pm 0.3$ & $8.3 \pm 0.3$ & 0.72 & $9.3 \pm 0.1$ & $9.2 \pm 0.1$ & 0.48 & $<0.01$ & 0.25 \\
\hline Platelet, $\times 10^{3} / \mu \mathrm{L}$ & $514.8 \pm 21.6$ & $537.6 \pm 20.4$ & 0.45 & $533.3 \pm 18.6$ & $555.4 \pm 17.6$ & 0.40 & $<0.01$ & 0.05 \\
\hline Leukocytes, $\times 10^{3} / \mu \mathrm{L}$ & $10.72 \pm 0.78$ & $8.68 \pm 0.63$ & 0.05 & $11.96 \pm 0.77$ & $11.56 \pm 0.73$ & 0.51 & $<0.01$ & 0.86 \\
\hline Lymphocytes, $\times 10^{3} / \mu \mathrm{L}$ & $5.8 \pm 0.3$ & $5.0 \pm 0.3$ & 0.09 & $6.5 \pm 0.2$ & $6.2 \pm 0.2$ & 0.33 & $<0.01$ & 0.74 \\
\hline Granulocytes, $\times 10^{3} / \mu \mathrm{L}$ & $4.08 \pm 0.55$ & $3.02 \pm 0.42$ & 0.11 & $4.22 \pm 0.55$ & $4.38 \pm 0.57$ & 0.63 & $<0.01$ & 0.90 \\
\hline Monocytes, $\times 10^{3} / \mu \mathrm{L}$ & $0.54 \pm 0.11$ & $0.33 \pm 0.11$ & 0.19 & $1.04 \pm 0.08$ & $0.98 \pm 0.07$ & 0.58 & $<0.01$ & 0.29 \\
\hline
\end{tabular}

${ }^{1}$ Day of weaning $=49 \mathrm{~d}$ of age. Control = calves received injections with saline (saline solution 0.9\%, Valley Vet Supply, Marysville, KS); rbST $=$ calves received 1.5 to $1.8 \mathrm{mg} / \mathrm{kg}$ of recombinant bST (Posilac, Elanco Animal Health, Greenfield, IN) every $7 \mathrm{~d}$ from 21 to $63 \mathrm{~d}$ of life. Trt $=$ treatment 

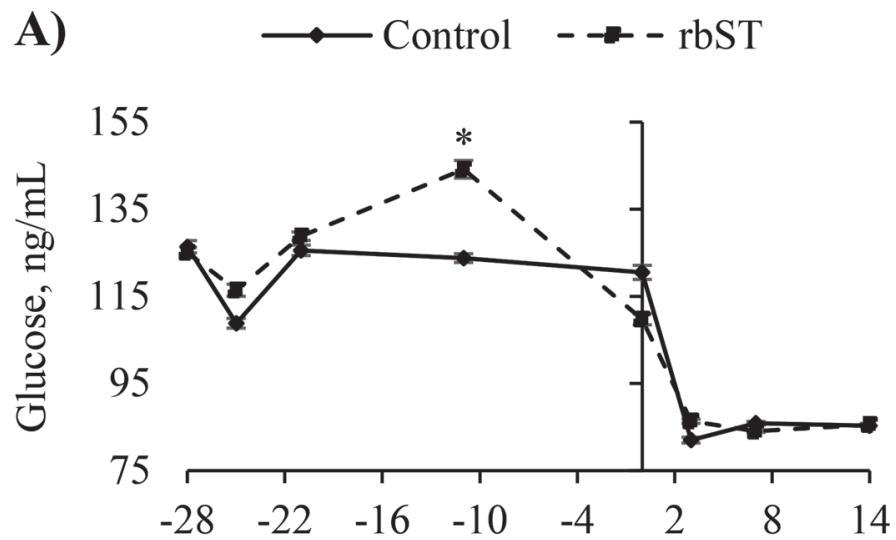

B)

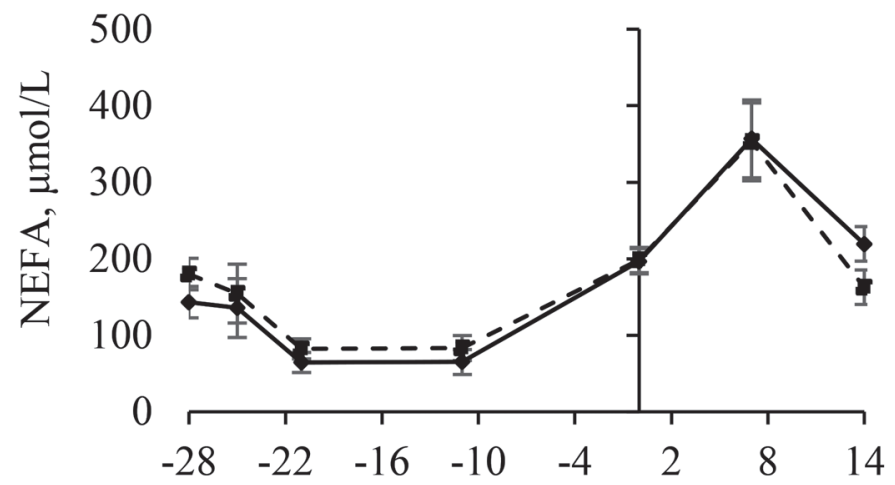

C)

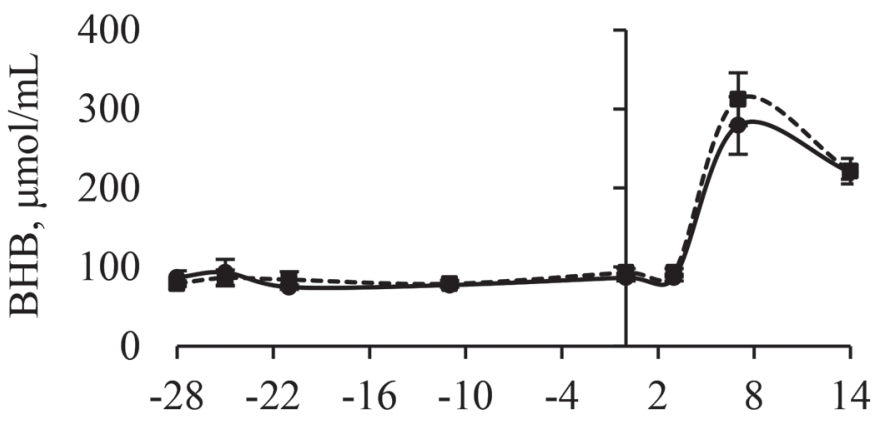

Day relative to weaning

Figure 7. Effect of recombinant (r)bST treatment on concentrations of (A) glucose, (B) nonesterified fatty acid (NEFA), and (C) BHB. Control $=$ calves received injections with saline (saline solution $0.9 \%$, Valley Vet Supply, Marysville, KS); rbST = calves received 1.5 to $1.8 \mathrm{mg} / \mathrm{kg}$ of rbST (Posilac, Elanco Animal Health, Greenfield, IN) every $7 \mathrm{~d}$ from 21 to $63 \mathrm{~d}$ of life. At enrollment, we found no differences between treatments regarding concentrations of glucose $(P=0.87)$, fatty acids $(P=0.22)$, and BHB $(P=0.56)$. Glucose: treatment $(P=$ $0.20)$, day $(P<0.01)$, and interaction between treatment and day $(P$ $=0.07)$. Fatty acid: treatment $(P=0.97)$, day $(P<0.01)$, and interaction between treatment and day $(P=0.49)$. $\beta$-Hydroxybutyrate: treatment $(P=0.28)$, day $(P<0.01)$, and interaction between treatment and day $(P=0.84)$. Error bars represent the SEM. receptors and the consequent low IGF-1 concentrations in the presence of high GH concentrations (Lucy et al., 2009; Silva et al., 2017b), may in part be explained by a subtle decrease in nutrient intake and the onset of negative energy balance. Similar to an experiment conducted with periparturient dairy cows (Silva et al., 2015, 2017a,b), rbST treatment had no effect on insulin concentration and only marginally increased glucose $-11 \mathrm{~d}$ relative weaning. These results suggest that weaning decisions regarding calves fed ad libitum milk or milk replacer need to be made on a calf-by-calf basis, taking into consideration the individual intake of starter whenever possible.
A)

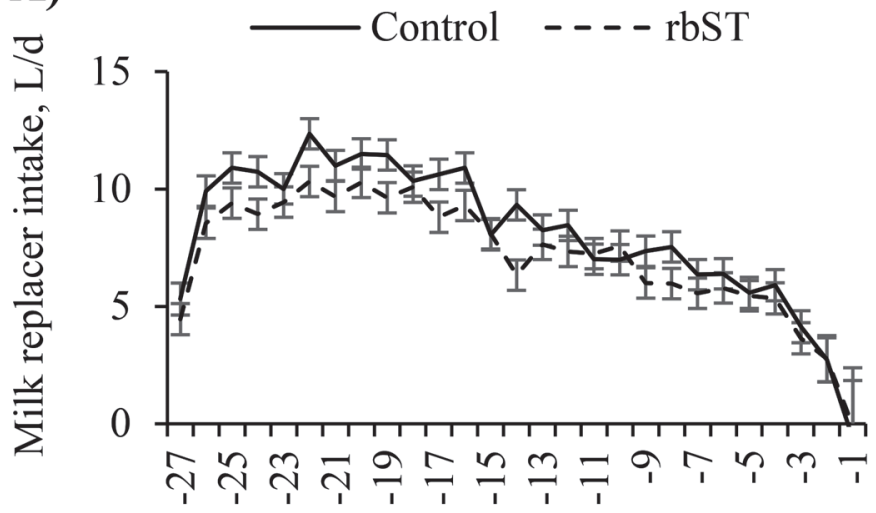

B)

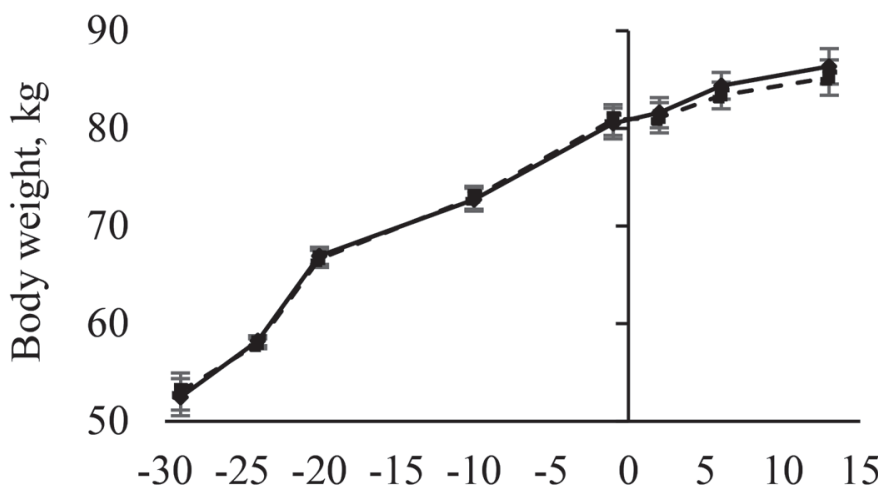

Day relative to weaning

Figure 8. Effect of recombinant (r)bST treatment on (A) milk replacer intake and (B) live BW. Control = calves received injections with saline (saline solution $0.9 \%$, Valley Vet Supply, Marysville, KS); $\mathrm{rbST}=$ calves received 1.5 to $1.8 \mathrm{mg} / \mathrm{kg}$ of $\mathrm{rbST}$ (Posilac, Elanco Animal Health, Greenfield, IN) every $7 \mathrm{~d}$ from 21 to $63 \mathrm{~d}$ of life. Milk replacer intake: treatment $(P=0.02)$, day $(P<0.01)$, and interaction between treatment and day $(P=0.50)$. Live BW at birth $(P=0.65)$ and at enrollment $(P=0.83)$ were not different between treatments. Live BW: treatment $(P=0.81)$, day $(P<0.01)$, and interaction between treatment and day $(P=0.94)$. Error bars represent the SEM. 
Contrary to our hypotheses, rbST-induced increases in GH and IGF-1 concentrations did not lead to improvements in PMN phagocytosis and oxidative burst. Additionally, treatment with rbST did not increase anti-ovalbumin IgG concentration. Treatment with rbST tended to upregulate the expression of CD62L and CD18 by granulocytes and CD62L by lymphocytes, particularly before weaning. Silva et al. (2015) demonstrated that treatment of periparturient cows with rbST increased PMN phagocytosis and oxidative burst by approximately 30\%, intensity of expression of CD62L by approximately $20 \%$, and anti-ovalbumin IgG concentration by approximately $50 \%$ between -14 and $0 \mathrm{~d}$ relative to calving. The mechanisms of action of GH and IGF-1 on immune cells may be autocrine, paracrine, or endocrine. Mononuclear leukocytes from rats have the ability to produce GH (Weigent et al., 1992), and leukocytes express receptors for GH and IGF-1 (Tapson et al., 1988; Silva et al., 2017c). The role of GH and IGF-1 on immune function has been studied at length in humans and rodents. Kiess et al. (1983) demonstrated that human GH induces proliferation of peripheral blood lymphocytes. Insulin-like growth factor-1 is an important factor in proliferation, differentiation, and hypertrophy of various cell types, including immune cells (LeRoith and Roberts, 1991). Culture of human granulocytes in the presence of different concentrations of IGF-1 reduced the percentage of apoptotic granulocytes by 34 to $40 \%$ compared with culture of granulocytes in the absence of IGF-1 (Kooijman et al., 2002). Similarly, granulocyte cultured with $6.5 \mathrm{n} M$ IGF-1 had a $45 \%$ decrease in DNA fragmentation compared with granulocytes cultured in the absence of IGF-1 (Kooijman et al., 2002). Culture of PMN with human growth hormone (100 to 1,000 ng/ $\mathrm{mL}$ ) or IGF-1 (100 to $1,000 \mathrm{ng} / \mathrm{mL}$ ) increased the percentage of $E$. coli killed and increased the expression of CD11, the $\alpha$ component of integrins that mediates adhesion of leukocytes to the endothelium, an important step in leukocyte transmigration (Inoue et al., 1998). Treatment of humans and rats deficient in GH with ST increased circulating concentrations of IGF-1, PMN, and antibodies (Kimata and Yoshida, 1994; Ibañez et al., 2005; Sohmiya et al., 2005). Piglets treated with ST before weaning and transportation had increased IgM concentrations (Kojima et al., 2008) and mice treated with ST had increased IGF-1 and IgG, IgM, and IgA concentrations (Sohmiya et al., 2005). Smaniotto et al. (2004) demonstrated that treatment of mice with $\mathrm{GH}$ increased the number of CD62L+ $\mathrm{T}$ cells and the expression of CD62L, and Ryu et al. (2000) demonstrated that treatment with GH enhanced adhesion of human neutrophils. Although culture of human PMN in the presence of $\mathrm{GH}$ had no effect on expression of
CD11b, culture of human PMN in the presence of IGF1 increased the intensity of expression of CD11b (Inoue et al., 1998). Questions remain whether rbST-induced upregulation of CD62L by granulocytes and lymphocytes and that of CD18 by granulocytes are sufficient to improve health of calves around weaning. Although the stress and metabolic challenge of weaning may have blunted the positive effects of GH and IGF-1 on the immune parameters described previously, treatment of periparturient cows with rbST produced similar changes in GH and IGF-1 concentrations and increased PMN function and IgG concentration in the presence of high cortisol, fatty acid, and BHB concentrations (Silva et al., 2015). It is possible that the GH and IGF-1 concentration of control calves in the current experiment was sufficient to ensure proper function of immune cells or that the increases in GH and IGF-1 concentrations in response to $\mathrm{rbST}$ treatment were insufficient to effectively change the immune parameters evaluated herein.

In the current experiment, nearly all immune parameters evaluated were reduced around weaning. Whereas expression of CD62L decreased progressively from -28 to $0 \mathrm{~d}$ relative to weaning and expression of CD18 decreased progressively from -28 to $14 \mathrm{~d}$ relative to weaning, PMN intensity of phagocytosis and oxidative burst decreased transiently at weaning and $7 \mathrm{~d}$ after weaning, respectively, mostly returning to preweaning levels $7 \mathrm{~d}$ later. Hulbert et al. (2011a) demonstrated a tendency for the intensity of PMN phagocytosis to decrease when liquid feed was consolidated into 1 feeding per day early in life. Additionally, calves weaned at $27 \mathrm{~d}$ of age that reached $900 \mathrm{~g} / \mathrm{d}$ of starter intake sooner (1 to $8 \mathrm{~d}$ after start of weaning) had greater intensity of expression of L-selectin and $\beta 2$-integrin at weaning and $7 \mathrm{~d}$ later (Hulbert et al., 2011b). This leads to speculation that the nutritional challenge associated with weaning, and the consequent changes in concentrations of metabolites, may be associated with impaired PMN function and altered granulocyte, lymphocyte, and CD14+ monocyte expression of adhesion molecules. Ster et al. (2012) demonstrated that increasing doses of fatty acid reduced concanavalin A-induced mononuclear cell proliferation and PMN phagocytosis intensity. Scalia et al. (2006) demonstrated that increasing concentrations of fatty acids increased PMN oxidative burst, but it reduced the viability and increased the necrosis of PMN. In the current experiment, none of the metabolites measured were associated with percentage of PMN positive for phagocytosis and oxidative burst and PMN oxidative burst intensity, but fatty acid concentration was positively associated with PMN phagocytosis intensity (data not shown). It is important to note that it is unclear whether the transient changes in PMN function and expression of adhesion molecules by granulocyte 
and lymphocyte are sufficient to predispose calves to infectious diseases.

In the current experiment, weaning was associated with an increase in haptoglobin concentration. Calves treated with $\mathrm{rbST}$, however, had reduced haptoglobin concentration at $3 \mathrm{~d}$ relative to weaning compared with control calves. Hulbert et al. (2011a) demonstrated that haptoglobin concentrations decreased from 45 to $66 \mathrm{~d}$ of age. Silva et al. (2015) demonstrated that rbSTtreated periparturient cows had reduced haptoglobin concentration $7 \mathrm{~d}$ postpartum compared with untreated cows. Haptoglobin is an acute phase protein produced mainly in the liver in response to infectious diseases, particularly respiratory diseases (Seppä-Lassila et al., 2015). The reduced haptoglobin concentration $3 \mathrm{~d}$ after weaning and the reduced hematocrit throughout the experiment among rbST-treated calves is an indication that rbST treatment reduced inflammation, but it is unclear whether this resulted from reduced incidence of diseases. Growth hormone therapy decreased the haptoglobin concentrations of severely burned human patients (Jeschke et al., 2000). Growth hormone-induced IGF-1 increase may modulate acute phase response by decreasing IL-1 expression, leading to a decrease in type 1 acute phase proteins and increased in constitutive hepatic proteins (Jarrar et al., 1997; Jeschke et al., 2000). Steers challenged in vivo with $E$. coli endotoxin had reduced tumor necrosis factor (TNF)- $\alpha$ concentration from 1 to $3 \mathrm{~h}$ following challenge and greater packed cell volume from 1 to $4 \mathrm{~h}$ after challenge (Elsasser et al., 1994; Elsasser et al., 1996). Haeffner et al. (1997) demonstrated that promonocytic cells engineered by gene transfer to produce GH secreted less TNF- $\alpha$ in response to an LPS challenges and that GH treatment inhibited TNF- $\alpha$ secretion by human monocytes and macrophages. The effects of rbST treatment on the severity of inflammatory response and secretion of proinflammatory cytokines in weaning calves should be further evaluated because prolonged and uncontrolled inflammatory response might be detrimental to the individual and result in increased morbidity and mortality (Moshage, 1997).

Milk replacer intake of rbST-treated calves from -27 to $-1 \mathrm{~d}$ relative to weaning was approximately $11 \%$ lower than control calves. Nonetheless, BW, ADG, and wither height were not affected by rbST treatment. In the current experiment it was not possible to determine individual starter intake because calves were group housed. Hammon et al. (2003) demonstrated that calves receiving $500 \mathrm{mg}$ of rbST every $14 \mathrm{~d}$ from 3 to $42 \mathrm{~d}$ of age had greater BW at 6 wk of age than control calves. Holzer et al. (1999, 2000) demonstrated that Holstein-Friesian bull calves treated with rbST from approximately 5 to 8 mo of age had greater ADG and greater conversion ratio than untreated calves. Several researchers have demonstrated that ST-treated animals have better feed efficiency, but this response is particularly dependent on nutritional status (Peters, 1986; Breier et al., 1988a,b). From the current experiment, no conclusions regarding feed efficiency of female calves can be extrapolated because starter intake was not recorded. We speculate that the lack of difference in BW between rbST-treated calves and control calves, despite the difference in milk replacer intake, reflects either greater feed efficiency of rbST-treated calves or compensatory consumption of starter by rbST-treated calves.

\section{CONCLUSIONS}

Treatment of weaning calves with rbST led to a significant increase in GH and IGF-1 concentrations, but weaning calves demonstrated a pattern of $\mathrm{GH}$ and IGF-1 similar to that of periparturient cows that undergo uncoupling of the somatotropic axis. This is an important finding because it indicates that calves fed milk replacer ad libitum that are not consuming sufficient starter by the time complete weaning occurs could undergo significant metabolic challenge that could hamper their immune system. In fact, all calves in the current experiment had a significant decrease in immune parameters around weaning. The lack of effect of rbST treatment on PMN phagocytosis and oxidative burst indicated that GH and IGF-1 concentrations are either not a limiting factor to immune function of weaning calves or that the inability of rbST treatment to maintain a high and constant IGF-1 concentration during weaning impedes any improvements in immune parameters. In fact, expression of CD62L and CD18 by granulocytes and lymphocytes was greater for rbSTtreated claves than control calves, particularly up to $-11 \mathrm{~d}$ relative to weaning when progressive weaning starter and IGF-1 concentrations started to decrease. Additional experiments are necessary to better elucidate the metabolic and immunological consequences of ad libitum feeding of milk replacer.

\section{ACKNOWLEDGMENTS}

The authors thank the owner and staff of the dairy in which this experiment was conducted.

\section{REFERENCES}

Barrington, G. M., and S. M. Parish. 2001. Bovine neonatal immunology. Vet. Clin. North Am. Food Anim. Pract. 17:463-476.

Breier, B. H., P. D. Gluckman, and J. J. Bass. 1988a. Influence of nutritional status and oestradiol-17B on plasma growth hormone, 
insulin-like growth factors I and II and the response to exogenous growth hormone in young steers. J. Endocrinol. 118:243-250.

Breier, B. H., P. D. Gluckman, and J. J. Bass. 1988b. The somatotrophic axis in young steers: Influence of nutritional status on oestradiol 17B on hepatic high- and low-affinity somatotrophic binding sites. J. Endocrinol. 116:169-177.

Chase, C. C. L., D. J. Hurley, and A. Reber. 2008. Neonatal immune development in the calf and its impact on vaccine response. Vet. Clin. North Am. Food Anim. Pract. 24:87-104.

Cooke, R. F., and J. D. Arthington. 2013. Concentrations of haptoglobin in bovine plasma determined by ELISA or a colorimetric method based on peroxidase activity. J. Anim. Physiol. Anim. Nutr. (Berl.) 97:531-536.

Elsasser, T. H., R. Fayer, T. S. Rumsey, and G. F. Hartnell. 1994. Recombinant bovine somatotropin blunts plasma tumor necrosis factor-alpha, cortisol, and thromboxane-B2 responses to endotoxin in vivo. Endocrinology 134:1082-1088.

Elsasser, T. H., M. Richards, R. Collier, and G. F. Hartnell. 1996. Physiological responses to repeated endotoxin challenge are selectively affected by recombinant bovine somatotropin administration to calves. Domest. Anim. Endocrinol. 13:91-103.

Gelsinger, S. L., A. J. Heinrichs, and C. M. Jones. 2016. A metaanalysis of the effects of preweaned calf nutrition and growth on first-lactation performance. J. Dairy Sci. 99:6206-6214.

Haeffner, A., N. Thieblemont, O. Deas, O. Marelli, B. Charpentier, A. Senik, S. D. Wright, N. Haeffner-Cavaillon, and F. Hirsch. 1997. Inhibitory effect of growth hormone on TNF-alpha secretion and nuclear factor-kappa B translocation in lipopolysaccharide-stimulated human monocytes. J. Immunol. 158:1310-1314.

Hammon, H. M., Y. Zbinden, H. Sauerwein, B. H. Breier, J. W. Blum, and S. S. Donkin. 2003. The response of the hepatic insulin-like growth factor system to growth hormone and dexamethasone in calves. J. Endocrinol. 179:427-435.

Holzer, Z., Y. Aharoni, A. Brosh, A. Orlov, and F. Buonomo. 2000 The influence of recombinant bovine somatotropin on dietary energy level-related growth of Holstein-Friesian bull calves. J. Anim. Sci. 78:621-628.

Holzer, Z., Y. Aharoni, A. Brosh, A. Orlov, J. J. Veenhuizen, and T. R. Kasser. 1999. The effects of long-term administration of recombinant bovine somatotropin (Posilac) and Synovex on performance, plasma hormone and amino acid concentration, and muscle and subcutaneous fat fatty acid composition in Holstein-Friesian bull calves. J. Anim. Sci. 77:1422-1430.

Hulbert, L. E., C. J. Cobb, J. A. Carroll, and M. A. Ballou. 2011a. The effects of early weaning on innate immune responses of Holstein calves. J. Dairy Sci. 94:2545-2556.

Hulbert, L. E., C. J. Cobb, J. A. Carroll, and M. A. Ballou. 2011b. Effects of changing milk replacer feedings from twice to once daily on Holstein calf innate immune responses before and after weaning. J. Dairy Sci. 94:2557-2565.

Hulbert, L. E., and S. J. Moisá. 2016. Stress, immunity, and the management of calves. J. Dairy Sci. 99:3199-3216.

Ibañez, L., A. Fucci, C. Valls, K. Ong, D. Dunger, and F. de Zegher. 2005. Neutrophil count in small-for-gestational age children: Contrasting effects of metformin and growth hormone therapy. J. Clin. Endocrinol. Metab. 90:3435-3439.

Inoue, T., H. Saito, T. Matsuda, K. Fukatsu, I. Han, S. Furukawa, S. Ikeda, and T. Muto. 1998. Growth hormone and insulin-like growth factor I augment bactericidal capacity of human polymorphonuclear neutrophils. Shock 10:278-284.

Jarrar, D., S. E. Wolf, M. G. Jeschke, R. J. Ramirez, M. DebRoy, C. K. Ogle, J. Papaconstantinou, and D. N. Herndon. 1997. Growth hormone attenuates the acute-phase response to thermal injury. Arch. Surg. 132:1171-1175.

Jeschke, M. G., R. E. Barrow, and D. N. Herndon. 2000. Recombinant human growth hormone treatment in pediatric burn patients and its role during the hepatic acute phase response. Crit. Care Med. $28: 1578-1584$.

Kampen, A. H., I. Olsen, T. Tollersrud, A. K. Storset, and A. Lund. 2006. Lymphocyte subpopulations and neutrophil function in calves during the first 6 months of life. Vet. Immunol. Immunopathol. 113:53-63.

Kiess, W., H. Holtmann, O. Butenandt, and R. Eife. 1983. Modulation of lymphoproliferation by human growth hormone. Eur. J. Pediatr. 140:47-50.

Kimata, H., and A. Yoshida. 1994. Differential effect of growth hormone and insulin-like growth factor-I, insulin-like growth factor-II, and insulin on $\mathrm{Ig}$ production and growth in human plasma cells. Blood 83:1569-1574.

Klindt, J., J. J. Ford, J. G. Berardinelli, and L. L. Anderson. 1983. Growth hormone secretion after hypophysial stalk transection in pigs. Proc. Soc. Exp. Biol. Med. 172:508-513.

Kojima, C. J., H. G. Kattesh, M. P. Robertsand, and T. Sun. 2008 Physiological and immunological responses to weaning and transport in the young pig: Modulation by administration of porcine somatotropin. J. Anim. Sci. 86:2913-2919.

Kooijman, R., A. Coppens, and E. Hooghe-Peters. 2002. Igf-I inhibits spontaneous apoptosis in human granulocytes. Endocrinology 143:1206-1212.

LeRoith, D., and C. T. Roberts Jr.. 1991. Insulin-like growth factor I (IGF-I): A molecular basis for endocrine versus local action? Mol. Cell. Endocrinol. 77:C57-C61.

Lucy, M. C., G. A. Verkerk, B. E. Whyte, K. A. Macdonald, L. Burton, R. T. Cursons, J. R. Roche, and C. W. Holmes. 2009. Somatotropic axis components and nutrient partitioning in genetically diverse dairy cows managed under different feed allowances in a pasture system. J. Dairy Sci. 92:526-539.

Martinez, N., C. A. Risco, F. S. Lima, R. S. Bisinotto, L. F. Greco, E. S. Ribeiro, F. Maunsell, K. N. Galvão, and J. E. Santos. 2012. Evaluation of peripartal calcium status, energetic profile, and neutrophil function in dairy cows at low or high risk of developing uterine disease. J. Dairy Sci. 95:7158-7172.

Miller-Cushon, E. K., R. Bergeron, K. E. Leslie, and T. J. DeVries. 2013. Effect of milk feeding level on development of feeding behavior in dairy calves. J. Dairy Sci. 96:551-564.

Moraes, J. G. M., L. G. D. Mendonç, P. R. B. Silva, A. A. Scanavez, K. N. Galvão, M. A. Ballou, M. Worku, and R. C. Chebel. 2017. Effects of intra-uterine infusion of $E$. coli lipopolysaccharide on uterine mRNA gene expression and peripheral polymorphonuclear leukocytes in Jersey cows diagnosed with purulent vaginal discharge. J. Dairy Sci. 100:4784-4796.

Moshage, H. 1997. Cytokines and the hepatic acute phase response. J. Pathol. 181:257-266.

Omidi-Mirzaei, H., M. Khorvash, G. R. Ghorbani, B. Moshiri, M. Mirzaei, A. Pezeshki, and M. H. Ghaffari. 2015. Effects of the step-up/step-down and step-down milk feeding procedures on the performance, structural growth, and blood metabolites of Holstein dairy calves. J. Dairy Sci. 98:7975-7981.

Peters, J. P. 1986. Consequences of accelerated gain and growth hormone administration for lipid metabolism in growing beef steers. J. Nutr. 116:2490-2503.

Ryu, H., J. H. Lee, K. S. Kim, S. M. Jeong, P. H. Kim, and H. T. Chung. 2000. Regulation of neutrophil adhesion by pituitary growth hormone accompanies tyrosine phosphorylation of Jak2, p125FAK, and paxillin. J. Immunol. 165:2116-2123.

Scalia, D., N. Lacetera, U. Bernabucci, K. Demeyere, L. Duchateau, and C. Burvenich. 2006. In vitro effects of nonesterified fatty acids on bovine neutrophils oxidative burst and viability. J. Dairy Sci. 89:147-154.

Schäff, C. T., J. Gruse, J. Maciej, M. Mielenz, E. Wirthgen, A. Hoeflich, M. Schmicke, R. Pfuhl, P. Jawor, T. Stefaniak, and H. M. Hammon. 2016. Effects of feeding milk replacer ad libitum or in restricted amounts for the first five weeks of life on the growth, metabolic adaptation, and immune status of newborn calves. PLoS One 11:e0168974.

Seppä-Lassila, L., T. Orro, B. Lassen, R. Lasonen, T. Autio, S. Pelkonen, and T. Soveri. 2015. Intestinal pathogens, diarrhoea and acute phase proteins in naturally infected dairy calves. Comp. Immunol. Microbiol. Infect. Dis. 41:10-16. 
Silva, P. R., K. M. Lobeck-Luchterhand, R. L. Cerri, D. M. Haines, M. A. Ballou, M. I. Endres, and R. C. Chebel. 2016. Effects of prepartum stocking density on innate and adaptive leukocyte responses and serum and hair cortisol concentrations. Vet. Immunol. Immunopathol. 169:39-46.

Silva, P. R. B., K. S. Machado, D. N. Lobao Da Silva, J. G. N. Moraes, D. H. Keisler, and R. C. Chebel. 2015. Effects of recombinant bovine somatotropin during the periparturient period on innate and adaptive immune responses, systemic inflammation, and metabolism of dairy cows. J. Dairy Sci. 98:4449-4464.

Silva, P. R., H. F. Soares, W. D. Braz, G. D. Bombardelli, J. A. Clapper, D. H. Keisler, and R. C. Chebel. 2017a. Effects of treatment of periparturient dairy cows with recombinant bovine somatotropin on health and productive and reproductive parameters. J. Dairy Sci. 100:3126-3142.

Silva, P. R. B., W. J. Weber, B. A. Crooker, R. J. Collier, W. W. Thatcher, and R. C. Chebel. 2017b. Hepatic mRNA expression for genes related to somatotropic axis, glucose and lipid metabolisms, and inflammatory response of periparturient dairy cows treated with recombinant bovine somatotropin. J. Dairy Sci. 100:39833999.

Silva, P. R. B., C. D. Nelson, J. P. Driver, W. W. Thatcher, and R. C. Chebel. 2017c. Effect of recombinant bovine somatotropin on leukocyte mRNA expression for genes related to cell energy metabolism, cytokine production, phagocytosis, oxidative burst, and adaptive immunity. J. Dairy Sci. 100:8471-8483.

Smaniotto, S., M. M. Ribeiro-Carvalho, M. Dardenne, W. Savino, and V. de Mello-Coelho. 2004. Growth hormone stimulates the selec- tive trafficking of thymic CD4+CD8- emigrants to peripheral lymphoid organs. Neuroimmunomodulation 11:299-306.

Soberon, F., E. Raffrenato, R. W. Everett, and M. E. Van Amburgh. 2012. Preweaning milk replacer intake and effects on long-term productivity of dairy calves. J. Dairy Sci. 95:783-793.

Sohmiya, M., I. Kanazawa, and Y. Kato. 2005. Effect of recombinant human GH on circulating granulocyte colony-stimulating factor and neutrophils in patients with adult GH deficiency. Eur. J. Endocrinol. 152:211-215.

Ster, C., M. C. Loiselle, and P. Lacasse. 2012. Effect of postcalving serum nonesterified fatty acids concentration on the functionality of bovine immune cells. J. Dairy Sci. 95:708-717.

Tapson, V. F., M. Born-Schnetzier, P. F. Pilch, D. M. Center, and J. S. Berman. 1988. Structural and functional characterization of the human T-lymphocyte receptor for insulin-like growth factor I in vitro. J. Clin. Invest. 82:950-957.

Vieira-Neto, A., I. R. P. Lima, F. Lopes Jr., C. Lopera, R. Zimpel, L. D. P. Sinedino, K. C. Jeong, K. Galvão, W. W. Thatcher, C. D. Nelson, and J. E. P. Santos. 2017. Use of calcitriol to maintain postpartum blood calcium and improve immune function in dairy cows. J. Dairy Sci. 100:5805-5823.

Weigent, D. A., J. B. Baxter, and J. E. Blalock. 1992. The production of growth hormone and insulin-like growth factor-l by the same subpopulation of rat mononuclear monocytes. Brain Behav. Immun. 6:365-376. 